\title{
Effect of Nitrogen Levels and Scheduling on Growth and Yield of Pigeon Pea in Integrated Approach
}

\author{
Gouthu Naga Panchavathi", B. P. Dhyani and U. P. Shahi \\ Department of Soil Science and Agricultural Chemistry, SVPUA\&T, \\ Meerut, Pin: 250110, India \\ *Corresponding author
}

\section{A B S T R A C T}

\section{Ke y w o r d s \\ Pigeon pea, Nutrient, \\ Management, Growth and Yield traits}

Article Info

Accepted:

11 June 2020 Available Online: 10 July 2020
A field experiment was conducted during Kharif season 2018 to evaluate the effect of nitrogen levels and scheduling on growth and yield of pigeon pea in integrated approach. The area situated at a latitude of $29^{\circ} 40^{\prime}$ North and longitude of $77^{\circ} 42^{\prime}$ East with an elevation of $237 \mathrm{~m}$ above mean sea level. Ten treatments consisting application of different level of nitrogen and vermicompost were tested in randomized block design with three replications. The data on growth, yield and its contributing traits were estimated as per the standard procedure. Growth parameters were comparatively better in the treatments where $40 \mathrm{~kg} \mathrm{~N}$ in two splits was applied. The highest grain yield and harvest index recorded in $T_{7}$ was found statistically at similar to the treatments $T_{6}, T_{9}, T_{10}$ and significantly higher than the rest of the treatments. The application of $\mathrm{N}, \mathrm{P}$ over control resulted approximately 25 percent improvement in grain yield. Integrated nutrient management practices are essential in realizing the higher productivity of pigeon pea and reducing cost of production on sustainable basis.

\section{Introduction}

Pulses a part of healthy, balanced diet have shown an important role in preventing illnesses such as cancer, diabetes and heart disease. Pulses are a low in fat, source of protein, with a high fiber content and low glycemic index. Pulses are very high in both soluble and insoluble fibers. Besides serving as an important source of protein for a large portion of the global population, pulses contribute to healthy soils and climate change mitigation through their nitrogen-fixing properties. Pigeon pea (Cajanus cajan (L.)
Mill sp.) is the second most important pulse crop of India after chickpea. It is cultivated in a multitude of production systems for a diversity of uses - grain as dhal, green seed as a vegetable and stalks as fuel wood.

Pigeon pea is commonly known in India as red gram or arhar or tur. However, major area under pigeon pea in India is lying between $14^{\circ} \mathrm{S}$ and $28^{\circ} \mathrm{N}$ latitudes. Pigeon pea is grown in India, predominantly, during kharif season both as a sole crop and as intercrop, though found in wide range of Agro-ecological situations. 
India's export percentage of pigeon pea is 1.57 and 8.96 during the year of 2015-16, 2016-17 (Anonymous, 2018). The productivity of pigeon pea during 2012-13 to 2016-17 varied from 776 to $854 \mathrm{Kg}^{-1}$. Area under the pulse in India was $29.28 \mathrm{M}$ ha in 2016-17 and in it share of pigeon pea was $18.4 \%$. The area and production of pigeon pea was recorded 5.38752 lakh ha and 45.99 lakh tones respectively during 2016-17 (Annual Report DPD 2016-17). Per captia per day and per year availability during 2016 was 43.0 g $15.7 \mathrm{~kg}$ respectively (Agriculture statistics at a glance, 2016). The percapita availability is slightly higher than $40 \mathrm{~g}$ as prescribed by ICMR. Low productivity may be resulted due to cultivation of pigeon pea in marginal soils with low soil fertility and least attention given to nutrient management. Nitrogen the most important plant growth promoting element increases the leaf area production that results in higher photosynthetic activity. Poor nitrogen supply will affect the plant growth and there by photosynthesis which affect symbiosis. Application of large quantities of fertilizer $\mathrm{N}$ inhibits $\mathrm{N}$ fixation, but low doses $(<30 \mathrm{~kg} \mathrm{~N}$ $\mathrm{ha}^{-1}$ ) of fertilizer $\mathrm{N}$ can stimulate early growth of legumes and increase their overall $\mathrm{N}$ fixation. The amount of this starter $\mathrm{N}$ must be defined in relation to available soil $\mathrm{N}$. (FAO, 2016).Although India stands first in area and production of this crop, still there is need to import this pulse crop from other countries, it is mainly due to the higher domestic consumption demands in our country. In pulses, the limited nitrogen fixation by legume- rhizobium symbiosis is the result of mineral nutrient deficiencies.

\section{Materials and Methods}

In order to further study the "Effect of nitrogen levels and scheduling on growth and yield of pigeon pea" a field experiment was carried out during the kharif season 2018 at
Crop Research Centre of Sardar Vallabhbhai Patel of Agriculture and Technology, Meerut (U.P). The soil of the experimental field was well drained, sandy loam in texture, alkaline in reaction $(\mathrm{pH} 7.80)$ and electrical conductivity $0.25 \mathrm{dSm}^{-1}$. The plot size was $12.6 \mathrm{~m}^{2}$ with $60 \mathrm{~cm} \times 15 \mathrm{~cm}$ spacing. Pigeon pea variety 'UPAS-120' was grown during mid-June keeping seed rate of $15 \mathrm{~kg} \mathrm{ha}^{-1}$. Growth observations were recorded at 35, 75 DAS and at harvest after sowing of the crop. Yield attributes were recorded at harvest. Crop was raised by adopting recommended package and practices. Ten treatments consisting application of different level of nitrogen and vermicompost viz $\mathrm{T}_{1}$ [Control (NPK) ], $\mathrm{T}_{2}(20: 50 \mathrm{~N}: \mathrm{P}), \mathrm{T}_{3}(20: 50: 40 \mathrm{~N}: \mathrm{P}$ : $\mathrm{K}), \mathrm{T}_{4}$ [30:50 (N: P) All N basal], $\mathrm{T}_{5}$ [ 30:50 (2/3 N Basal: $1 / 3 \mathrm{~N}$ top dress $35 \mathrm{DAS})$ ], $\mathrm{T}_{6}$ [40:50 (All N Basal)], $\mathrm{T}_{7}$ [40:50 (2/3 N Basal: $1 / 3 \mathrm{~N}$ top dress 35 DAS)], $\mathrm{T}_{8}$ 20:50 + Vermicompost (VC) @0.75 t/ha, T9 20:50+ VC@1.25 t/ha, T 10 20:50 + VC@1.5 t/ha were tested in randomized block design with three replications. The experimental results revealed that growth attributes (plant height, number of primary branches, dry matter accumulation), yield attributing traits (pods plant $^{-1}$, grains pod ${ }^{-1}$, pod weight plant ${ }^{-1}$, grain yield plant ${ }^{-1}$,test weight), yields viz., grain, straw and biological in pigeon pea differ significantly among the different treatments. The data related to various criteria used for treatment evaluation were analyzed statistically using standard statistical methods to tests their significance. The data recorded for important characters have also been depicted graphically for elucidation of the important trends wherever necessary.

\section{Results and Discussion}

Considering the scenario of Indian soil present investigation "Effect of nitrogen levels and scheduling on growth and yield of pigeonpea" was conducted. Nitrogen 
requirement for pulses is less therefore less attention had been paid towards the nitrogen management in pulses. The productivity of pulses in the country is low due to their cultivation in poor fertile soils as well as lower attention towards the management practices. Data regarding the effect of different nitrogen management treatments on various growth attributes viz., plant height, number of primary branches, dry matter accumulation, nodulation recorded at different intervals. Plant height of the crop is one of the important growth parameters. Higher level 40 $\mathrm{Kg} \mathrm{ha}{ }^{-1}$ of nitrogen application over recommended $20 \mathrm{Kg} \mathrm{N}$ ha $^{-1}$ resulted a significant improvement in plant at all the intervals. The results reveal that number of branches per plant differ significantly under the influence of different treatments. Initially the effect of $40 \mathrm{Kg} \mathrm{N}^{-1}$ was significant while at later stages the impact of 30 as well as $40 \mathrm{~kg} \mathrm{~N}$ application over recommended $\mathrm{N}$ was significant. Singh et al., 1998 who had reported that nitrogen treatment with increasing level up to $30 \mathrm{~kg} \mathrm{ha}^{-1}$ in pigeon pea resulted a significant effect on branching. Dry matter accumulation $\mathrm{g}$ plant $^{-1}$ increase with advancement in plant growth and reached to maximum at harvest.

\section{Effect of different treatments on growth parameters in pigeon pea:}

Data regarding the effect of $\mathrm{N}$ levels and scheduling on growth parameter are presented in Table 1\&2.Nitrogen levels with different schedule and vermicompost exhibited a significant effect on various growth parameters viz. plant height, number of primary branches, nodulation, and dry matter accumulation at different intervals of crop growth. Plant height increased with the advancement in crop growth. At 35 DAS maximum plant height $68.46 \mathrm{~cm}$ significantly higher than the treatments with exception of $\mathrm{T}_{4}, \mathrm{~T}_{7}, \mathrm{~T}_{10}$ was found in $\mathrm{T}_{6}$ where $40 \mathrm{~kg} \mathrm{~N}$ was applied as basal. At this interval treatments receiving higher basal $\mathrm{N}$ application produced taller plant. At 75DAS and harvest maximum plant height 129.43 and $188.13 \mathrm{~cm}$ respectively was found in $\mathrm{T}_{7}$ where $40 \mathrm{~kg} \mathrm{~N}$ was applied in two splits. Plant height decline by 6.05 percent in unfertilized plot than fertilized with recommended N P.Ghosh et al., (2006) reported that in soybean/ pigeon pea intercropping system, $\mathrm{N}$ is a limiting factor for growth and application of $100 \%$ NPK (30 $\mathrm{Kg} \mathrm{N})+4 \mathrm{t}$ FYM could meet $\mathrm{N}$ demand of pigeon pea in deficient soil. Finding also get conformity from the work of Meena et al., (2015) and Maktumsab et al., (2017).

At 35 DAS maximum number of branches per plant 4.98 significantly higher than $\mathrm{T}_{1}, \mathrm{~T}_{2}, \mathrm{~T}_{3}$, $\mathrm{T}_{5}$ and statistically at par with rest of the treatments were found in $\mathrm{T}_{6}$. At 75 DAS and harvesting maximum branches per plant were recorded in $T_{7}$ and $T_{6}$ respectively. It was clear here that the plot receiving more $\mathrm{N}$ either through chemical fertilizer or in integration produced more branches. The results reveal that the application of potassium or high dose of nitrogen showed a positive effect on number of branches per plant. The significant effect of $2 \%$ urea application on number of branches also had been reported by Kaur et al., (2015). Patil 2002 also reported that significant improvement on branches per plant with the application of 5 tons FYM.

Dry matter accumulation increased with advancement of crop age and reached to maximum at harvesting. It was influenced by different treatments at different days interval. AT every interval maximum dry matter accumulation was record $\mathrm{T}_{6}$ where $40 \mathrm{~kg} \mathrm{~N}$ was applied as basal. Application of potassium or additional nitrogen over recommended $\mathrm{N} \mathrm{P}$ also resulted a significant improvement in dry matter accumulation. It was also found that application of 1.25 or 1.5 
ton vermicompost over recommended $\mathrm{N} P$ also improved the dry matter significantly. Improvement in dry matter accumulation with additional $\mathrm{N}$ or vermicompost may be supposed with better plant growth. Singh (2007) reported the higher dry matter accumulation with the application of $50 \%$ RDF and 5tonne FYM.

Number of effective nodules at 75DAS decline from the numbers counted at previous observation (35 DAS) in all treatments. Minimum number of effective nodules 8.60 at DAS found in $T_{1}$ (control) were significantly lower than the remaining treatments. Minimum and significantly lower number of effective nodules 11.32 than the $\mathrm{T}_{6}, \mathrm{~T}_{7}, \mathrm{~T}_{8}, \mathrm{~T}_{9}$ and were found in control. Singh et al., 2009 also reported that application of $20 \mathrm{~kg} \mathrm{~N}$ as basal $+10 \mathrm{Kg} \mathrm{N}$ as foliar recorded more dry weight of nodules

\section{Effect of different treatments on yield attributing characters:}

Data regarding effect of $\mathrm{N}$ levels and scheduling on growth attributing characters are presented in Table 3 and the same is illustrated in Fig 1. Maximum number of pods per plant 107.73 significantly higher than $T_{1}$, $\mathrm{T}_{2}$ and statistically at par with rest of the treatments were found in $T_{7}$. Application of potassium as well as additional dose of nitrogen significantly improve the number of pods per plant. Maximum number of grains per pod 3.70 significantly higher than $T_{1}, T_{2}$, $\mathrm{T}_{3}$ and statistically at par with rest of the treatments were found in $T_{7}$. Application of various level of vermicompost over recommended $\mathrm{N}, \mathrm{P}$ or higher $\mathrm{N}$ level also resulted in more number of grains per pod. Maximum pod weight per plant $74.88 \mathrm{~g}$ significantly higher than the treatments with exception of $\mathrm{T}_{5}, \mathrm{~T}_{6}, \mathrm{~T}_{9}, \mathrm{~T}_{10}$ was found in $\mathrm{T}_{7}$ with the application of $40 \mathrm{~kg} \mathrm{~N}$ in two splits while minimum pods was found in control
$\left(\mathrm{T}_{1}\right)$. The effect of potassium application on pod weight per plant was non-significant. Similarly, the effect of $30 \mathrm{Kg} \mathrm{N}$ application as basal on pod weight per plant was nonsignificant. Maximum grain yield per plant $19.2 \mathrm{~g}$ significantly higher than the treatments with exceptions of $\mathrm{T}_{6}, \mathrm{~T}_{9}, \mathrm{~T}_{10}$ was found in $\mathrm{T}_{7}$ where $40 \mathrm{Kg} \mathrm{N}$ was applied in two split while minimum grain yield per plant 12.2 significantly lower than the treatments with exception of $\mathrm{T}_{2}$ in control.

Maximum test weight was found in $T_{7}$. The application of potassium over recommended $\mathrm{N}, \mathrm{P}$ could not exhibit any significant improvement in grain yield per plant however additional application of $\mathrm{N}$ or vermicompost over recommended $\mathrm{N}, \mathrm{P}$ resulted a significant improvement. Patil 2002 reported that application of $5 \mathrm{t} /$ ha FYM significantly increase the yield attributes in pigeon pea. Somnath et al., (2006) also reported that the half recommended dose of fertilizer +5 tonne press mud + rhizobium + PSB significantly increased leaf chlorophyll, N,P,K and yield attributing parameters viz. 1000 test weight, number of pods per plant and yield plot $^{-1}$ in pigeon pea.

\section{Effect of different treatments on yield of pigeon pea}

Data regarding the yield of pigeon pea as influenced by different treatments are shown in Table 4 and the same is illustrated in Fig 2. Maximum straw yield $8647 \quad \mathrm{~kg} \mathrm{ha}^{-1}$ statistically at par to the treatments with exception $\mathrm{T}_{1}, \mathrm{~T}_{2}, \mathrm{~T}_{3}$ was found in $\mathrm{T}_{7}$ where 40 $\mathrm{Kg} \mathrm{N}$ was applied in two splits. With few exceptions additional application of $\mathrm{N}$ and vermicompost over recommended $\mathrm{N}$ resulted a significant variation in straw yield. Increment in straw yield ranged from 6.4 to 13.3 percent due to additional application of nitrogen and vermicompost over recommended $\mathrm{N}, \mathrm{P}$. 
Table.1 Effect of nitrogen levels and scheduling on plant height $(\mathrm{cm})$ and number of branches at different stages of pigeon pea

\begin{tabular}{|c|c|c|c|c|c|c|}
\hline \multirow[t]{2}{*}{ Treatment } & \multicolumn{3}{|c|}{ Plant height (cm) } & \multicolumn{3}{|c|}{$\begin{array}{c}\text { Number of branches } \\
\text { plant }^{-1}\end{array}$} \\
\hline & $\begin{array}{c}35 \\
\text { DAS }\end{array}$ & $\begin{array}{l}75 \\
\text { DAS }\end{array}$ & Harvest & $\begin{array}{c}35 \\
\text { DAS }\end{array}$ & $\begin{array}{c}75 \\
\text { DAS }\end{array}$ & Harvest \\
\hline$T_{1}$ Control & 60.23 & 100.19 & 155.06 & 4.02 & 7.33 & 18.50 \\
\hline$T_{2} 20: 50 \mathrm{~N}: \mathrm{P}$ & 64.09 & 114.97 & 165.06 & 4.62 & 8.29 & 21.73 \\
\hline$T_{3}$ 20:50:40 N:P:K & 64.70 & 118.63 & 169.66 & 4.56 & 9.05 & 23.00 \\
\hline$T_{4} 30: 50(\mathrm{~N}: \mathrm{P})$ All $\mathrm{N}$ basal & 67.69 & 125.75 & 178.43 & 4.74 & 9.43 & 23.23 \\
\hline $\begin{array}{l}T_{5} \text { 30:50 (2/3 N Basal: } 1 / 3 \mathrm{~N} \text { top dress } 35 \\
\text { DAS }\end{array}$ & 65.38 & 126.04 & 183.60 & 4.65 & 9.40 & 23.10 \\
\hline$T_{6} 40: 50$ (All $\mathrm{N}$ basal) & 68.46 & 127.98 & 185.90 & 4.98 & 10.12 & 23.87 \\
\hline $\begin{array}{l}T_{7} 40: 50(2 / 3 \mathrm{~N} \text { basal }: 1 / 3 \mathrm{~N} \text { top dress } 35 \\
\text { DAS }\end{array}$ & 67.48 & 129.43 & 188.13 & 4.92 & 10.40 & 23.50 \\
\hline$T_{8} 20: 50+V C @ 0.75$ t/ha & 65.13 & 124.71 & 174.84 & 4.74 & 8.68 & 23.23 \\
\hline$T_{9} 20: 50+V C @ 1.25$ t/ha & 66.41 & 126.54 & 176.77 & 4.89 & 9.18 & 23.47 \\
\hline$T_{10} 20: 50+V C @ 1.5$ t/ha & 67.05 & 127.66 & 178.98 & 4.89 & 10.17 & 23.50 \\
\hline $\operatorname{SEm}( \pm)$ & 0.66 & 4.40 & 6.24 & 0.09 & 0.20 & 0.52 \\
\hline $\mathrm{CD}(\mathrm{P}=\mathbf{0 . 0 5})$ & 1.90 & 12.68 & 18.04 & 0.27 & 0.60 & 1.51 \\
\hline
\end{tabular}

Table.2 Effect of nitrogen levels and scheduling on dry matter accumulation (g plant $\left.{ }^{-1}\right)$ and on number of nodule plant ${ }^{-1} \&$ their dry weight $\left(\mathrm{mg} \mathrm{plant}^{-1}\right)$ at different stages of pigeon pea

\begin{tabular}{|c|c|c|c|c|c|c|c|}
\hline \multirow[t]{2}{*}{ Treatment } & \multicolumn{3}{|c|}{$\begin{array}{c}\text { Dry matter accumulation } \\
\left(\mathrm{g} \text { plant }^{-1}\right)\end{array}$} & \multicolumn{2}{|c|}{$\begin{array}{c}\text { Number of nodules } \\
\text { plant }^{-1}\end{array}$} & \multicolumn{2}{|c|}{$\begin{array}{l}\text { Nodules dry weight } \\
\left(\text { mg plant }^{-1}\right)\end{array}$} \\
\hline & $\begin{array}{c}35 \\
\text { DAS }\end{array}$ & $\begin{array}{c}75 \\
\text { DAS }\end{array}$ & Harvest & $\begin{array}{c}35 \\
\text { DAS }\end{array}$ & $\begin{array}{c}75 \\
\text { DAS }\end{array}$ & $\begin{array}{c}35 \\
\text { DAS }\end{array}$ & $\begin{array}{c}75 \\
\text { DAS }\end{array}$ \\
\hline$T_{1}$ Control & 2.81 & 41.47 & 99.70 & 11.32 & 8.60 & 14.06 & 11.78 \\
\hline$T_{2} 20: 50 \mathrm{~N}: P$ & 3.00 & 44.87 & 102.50 & 11.39 & 8.72 & 14.29 & 12.23 \\
\hline$T_{3}$ 20:50:40 N:P:K & 3.20 & 47.97 & 106.93 & 11.42 & 9.03 & 15.02 & 12.69 \\
\hline $\begin{array}{l}\mathbf{T}_{4} \quad 30: 50 \quad(\mathbf{N}: P) \\
\text { basal }\end{array}$ & 3.26 & 54.40 & 109.17 & 11.49 & 9.26 & 15.36 & 13.28 \\
\hline $\begin{array}{l}T_{5} 30: 50(2 / 3 \mathrm{~N} \text { Basal: } 1 / 3 \\
\mathrm{N} \text { top dress } 35 \mathrm{DAS}\end{array}$ & 3.09 & 52.03 & 111.50 & 12.42 & 9.52 & 15.96 & 13.86 \\
\hline$T_{6} 40: 50$ (All N basal) & 3.43 & 57.73 & 116.17 & 12.92 & 10.28 & 16.23 & 14.89 \\
\hline $\begin{array}{l}T_{7} 40: 50(2 / 3 \mathrm{~N} \text { basal }: 1 / 3 \\
\mathrm{N} \text { top dress 35DAS }\end{array}$ & 3.23 & 55.84 & 113.33 & 12.63 & 9.86 & 17.09 & 14.56 \\
\hline$T_{8} 20: 50+V C @ 0.75 t / h a$ & 3.12 & 51.30 & 111.17 & 13.23 & 10.58 & 16.59 & 15.63 \\
\hline$T_{9} 20: 50+V C @ 1.25$ t/ha & 3.23 & 54.40 & 112.50 & 13.56 & 10.96 & 17.23 & 15.86 \\
\hline$T_{10} 20: 50+V C @ 1.5$ t/ha & 3.38 & 55.10 & 113.00 & 14.23 & 11.23 & 17.85 & 16.25 \\
\hline $\operatorname{SEm}( \pm)$ & 0.06 & 0.65 & 1.50 & 0.45 & 0.36 & 0.58 & 0.52 \\
\hline CD $(\mathbf{P}=0.05)$ & 0.18 & 1.89 & 4.34 & 1.31 & 1.03 & 1.67 & 1.51 \\
\hline
\end{tabular}


Table.3 Effect of nitrogen levels and scheduling on yield attributes of pigeon pea

\begin{tabular}{|c|c|c|c|c|c|}
\hline Treatments & $\begin{array}{l}\text { Number of } \\
\text { pods plant }^{-1}\end{array}$ & $\begin{array}{l}\text { Number of } \\
\text { grain pod }^{-1}\end{array}$ & $\begin{array}{c}\text { Pod } \\
\text { weight } \\
\text { plant }^{-1}(g)\end{array}$ & $\begin{array}{c}\text { Grain } \\
\text { yield } \\
\text { plant }^{-1}(\mathrm{~g})\end{array}$ & $\begin{array}{c}\text { Test } \\
\text { weight }(g)\end{array}$ \\
\hline $\mathbf{T}_{1}$ Control & 83.28 & 2.93 & 64.52 & 12.2 & 79.20 \\
\hline $\mathrm{T}_{2} 20: 50 \mathrm{~N}: \mathrm{P}$ & 91.84 & 3.23 & 66.90 & 13.7 & 80.35 \\
\hline$T_{3}$ 20:50:40 N:P:K & 98.88 & 3.37 & 68.66 & 14.2 & 82.42 \\
\hline $\mathbf{T}_{4} \mathbf{3 0 : 5 0}(\mathbf{N}: \mathbf{P})$ All $\mathbf{N}$ basal & 101.43 & 3.50 & 69.41 & 16.2 & 83.75 \\
\hline $\begin{array}{l}\mathrm{T}_{5} 30: 50(2 / 3 \mathrm{~N} \text { Basal: } 1 / 3 \\
\mathrm{N} \text { top dress } 35 \text { DAS }\end{array}$ & 102.80 & 3.63 & 71.23 & 16.8 & 83.76 \\
\hline$T_{6} 40: 50$ (All N basal) & 103.22 & 3.50 & 71.41 & 17.6 & 85.74 \\
\hline $\begin{array}{l}\mathrm{T}_{7} 40: 50(2 / 3 \mathrm{~N} \text { basal }: 1 / 3 \\
\mathrm{N} \text { top dress } 35 \mathrm{DAS}\end{array}$ & 107.73 & 3.70 & 74.88 & 19.2 & 86.74 \\
\hline$T_{8} 20: 50+V C @ 0.75$ t/ha & 101.33 & 3.50 & 70.60 & 16.9 & 85.72 \\
\hline$T_{9} 20: 50+V C @ 1.25$ t/ha & 104.59 & 3.67 & 71.20 & 18.1 & 84.52 \\
\hline$T_{10} 20: 50+V C @ 1.5$ t/ha & 106.19 & 3.57 & 71.55 & 18.8 & 86.71 \\
\hline $\operatorname{SEm}( \pm)$ & 3.60 & 0.09 & 1.29 & 0.60 & 2.39 \\
\hline $\mathrm{CD}(\mathrm{P}=\mathbf{0 . 0 5})$ & 10.40 & 0.26 & 3.74 & 1.80 & 6.91 \\
\hline
\end{tabular}

Table.4 Effect of nitrogen levels and scheduling on grain, strawand biological yield pigeon pea

\begin{tabular}{|c|c|c|c|}
\hline Treatments & $\begin{array}{c}\text { Grain yield } \\
\text { (kg/ha) }\end{array}$ & $\begin{array}{c}\text { Straw yield } \\
\text { (kg/ha) }\end{array}$ & $\begin{array}{c}\text { Biological } \\
\text { yield(kg/ha) }\end{array}$ \\
\hline $\mathbf{T}_{1}$ Control & 914.0 & 6600.7 & 7514.7 \\
\hline $\mathrm{T}_{2}$ 20:50 N:P & 1142.0 & 7629.5 & 8851.5 \\
\hline$T_{3} 20: 50: 40$ N:P:K & 1185.0 & 7542.9 & 8807.9 \\
\hline $\mathrm{T}_{4} 30: 50$ (N:P) All N basal & 1349.4 & 8120.7 & 9430.1 \\
\hline$T_{5} 30: 50$ (2/3 N Basal: $1 / 3 \mathrm{~N}$ top dress 35 DAS & 1401.6 & 8353.5 & 9675.1 \\
\hline$T_{6} 40: 50$ (All $\mathbf{N}$ basal) & 1468.0 & 8096.7 & 10097.8 \\
\hline$T_{7} 40: 50(2 / 3 \mathrm{~N}$ basal :1/3 $\mathrm{N}$ top dress 35DAS & 1601.0 & 8647.0 & 10248.0 \\
\hline$T_{8} 20: 50+V C @ 0.75$ t/ha & 1404.7 & 8169.0 & 9573.7 \\
\hline$T_{9} 20: 50+V C @ 1.25$ t/ha & 1508.6 & 8517.8 & 10026.4 \\
\hline$T_{10} 20: 50+V C @ 1.5$ t/ha & 1563.4 & 8439.1 & 10185.1 \\
\hline $\operatorname{SEm}( \pm)$ & 49.758 & 287.644 & 331.46 \\
\hline $\mathrm{CD}(\mathrm{P}=0.05)$ & 148.984 & 861.24 & 958.73 \\
\hline
\end{tabular}


Fig.1 Effect of nitrogen levels and scheduling on yield attributes of pigeon pea

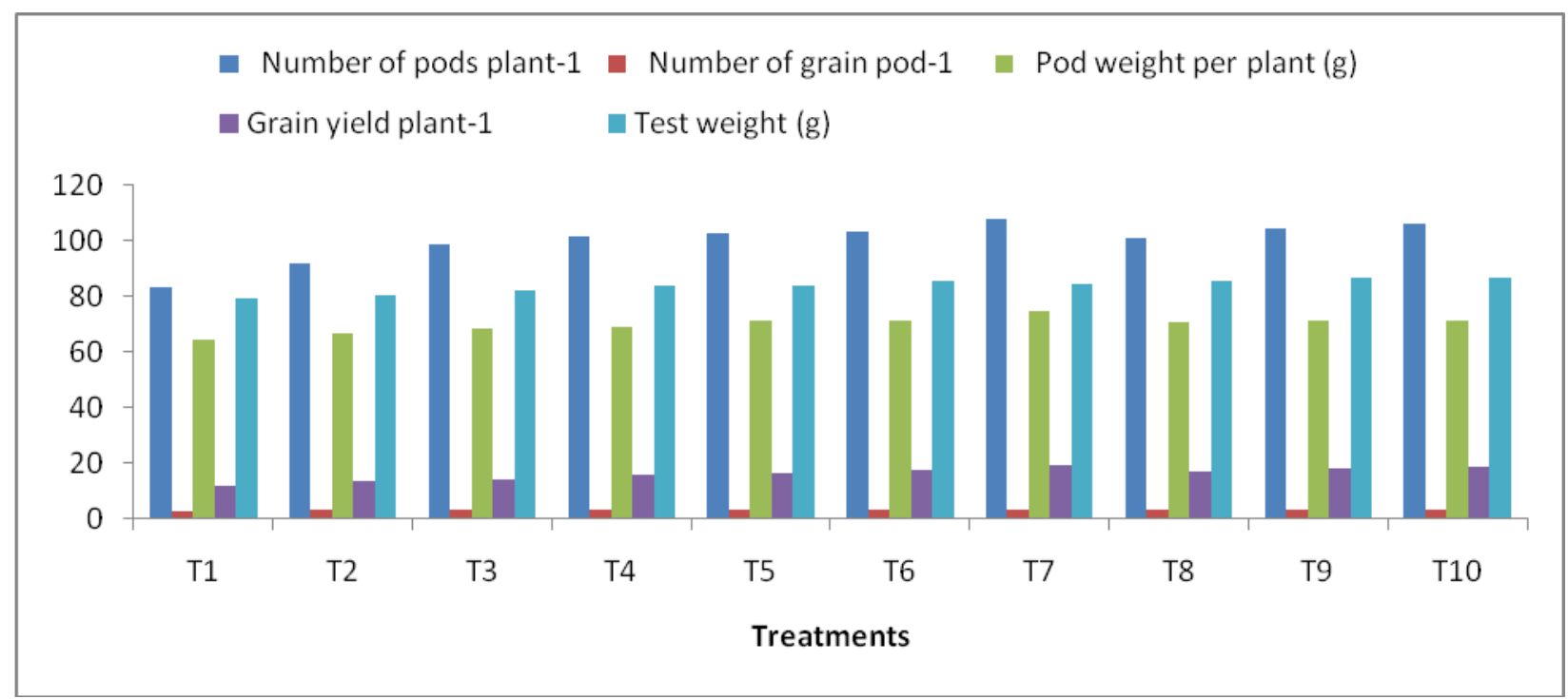

Fig.2 Effect of nitrogen levels and scheduling on grain, straw and biological yield pigeon pea

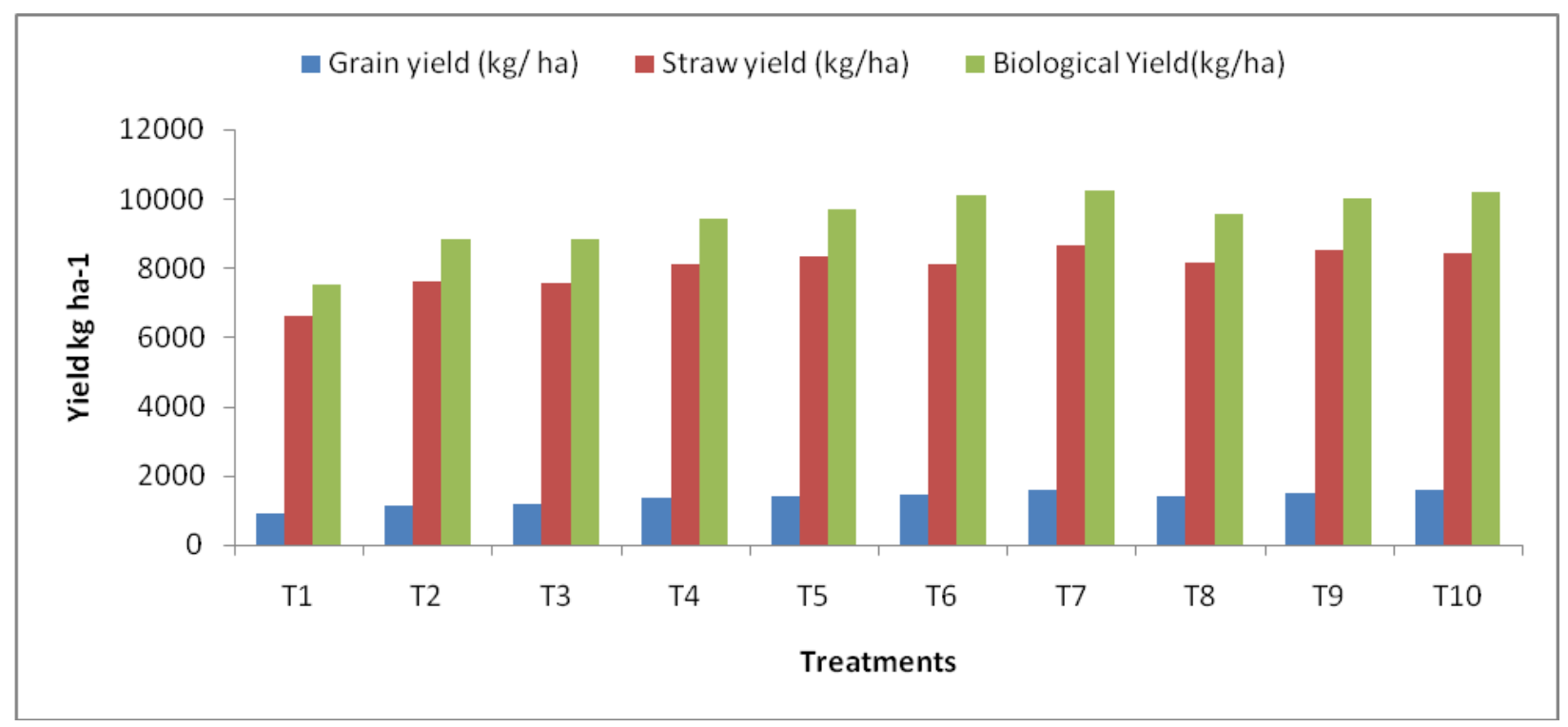

Maximum biological yield $10248.0 \mathrm{~kg} \mathrm{ha}^{-1}$ statistically at par to the treatments with exception $T_{1}, T_{2}, T_{3}$ was found in $T_{7}$ where 40 $\mathrm{Kg} \mathrm{N}$ was applied in two split while minimum $7514.7 \mathrm{~kg} \mathrm{ha}^{-1}$ significantly lower than the remaining treatments in control $\mathrm{T}_{1}$ significant increase in grain yield Biological yield decline by 15.1 percent in unfertilized plot than fertilized with recommended dose of nitrogen and phosphorus. Tomar (2013) also reported a significant improvement in grain yield with increasing $\mathrm{N}$ levels.

In conclusion from the results obtained in the present study it seems that the nitrogen application in pigeon pea should be increased since additional application of nitrogen over recommended $\mathrm{N}$ yielded significantly higher. For most of legumes the recommendation of nitrogen is $20 \mathrm{~kg} \mathrm{ha}^{-1}$ while removal is much 
higher. The recommendation was made long back when soils were having substantial organic matter and nitrogen but now Indian soils are poor in nitrogen and organic matter and in such condition application of $20 \mathrm{~kg} \mathrm{~N}$ $\mathrm{ha}^{-1}$ may not be enough for pulses. Growth parameters were comparatively better in the treatments where $40 \mathrm{Kg} \mathrm{N}$ in two splits was applied. The highest grain yield and harvest index recorded in $T_{7}$ was found statistically at similar to the treatments $\mathrm{T}_{6}, \mathrm{~T}_{9}, \mathrm{~T}_{10}$ and significantly higher than the rest of the treatments. The application of $\mathrm{N}, \mathrm{P}$ over control resulted approximately 25 percent improvement in grain yield. This recommendation is based on the assumption that there will be sufficient biological nitrogen fixation as well as soil will also supplement the nitrogen. This finding is also supported with the application of vermicompost over recommended $\mathrm{N}$ as vermicompost will also supply additional nitrogen. Integrated nutrient management will also be equally effective in enhancing pigeon pea yield as well as maintaining soil fertility.

\section{References}

Anonymous, (2018). Commodity Profile for Pulses-February 2018.

Agriculture Statistics at a glance 2016. Directorate of Economics and statistics, MinistryAgriculture, Govt of India.

Annual report (2016-17). Directorate of Pulse development.

F.A.O. 2016. International year of pulses, http://www.fao.org/pulses-2016/en/.

Ghosh, Manoranjanmohanty, D.K Painuli (2006). Growth competition yields advantage and economics in soyabean / pigeon pea intercropping system in semiarid tropics. Field Crops Research 96 (1): 90-97

Kaur, Gagandeep, Ghai, Navita, Kaur, Jagmeet and Singh ,Sarvjeet (2015).Growth efficiency and yield of pigeon pea (Cajanus cajan) as affected by foliar application of mineral nutrients. Journal of Plant Science and Research 2(2): 113130.

Maktumsab, M. T., Guled, M. B and Surakod, V. S. (2017).Effect of varying levels of plant population and nutrient management in pigeon pea under zai methodof cultivation. Plant Archives 17(1):141-144.

Meena, M.k. Hulihalli, U.K and Arvind Kumar (2015). Effect of fertility and planting geometry

on growth and yield of medium duration pigeon pea hybrid ICPH-2671 Res J.Agric. Sci.2(3): 715-718.

Patil, A. B. (2002).Integrated nutrient management in pigeon pea (Cajanus cajan (L.) Millsp. M. Sc. (Agri.) Thesis (Unpublished) submitted to Gujarat Agricultural University, Sardar krushinagar.

TomarTejveer Singh, Tomar Savita and Singh Subey, (2013). Effect of phosphorus and biofertilizers in pigeon pea and its residual effect on the productivity. Ann. Agric. New Series 36 (1) 38-43.

Singh, S.P., Singh, S.P. and Mishra, P.K.1998.Response of short duration pigeon pea (Cajanus cajan L. Mill sp.) to nitrogen, Rhizobium inoculation and phosphorus. Indian Journal of Agronomy .43(4): 681-684.

Singh, R.S. (2007). Effect of organic and inorganic sources of nutrition on productivity of long duration pigeon pea (Cajanus cajan (L.) Millsp). Environment and Ecology, 25(3A): 768-770.

Singh., S.P., Srivastava, G.P., Panday, A.C., Pradeep prasad., Manish kumar., Krasna., G, Anil kumar. and Sanjeev kumar., (2009). Effect of nitrogen levels and population densities on root, nodules and yield of black gram. Inter. J. tropical. agric., 27(1-2): 315-318.

Somnath, Kandkar, Jain (2006). Effect of different fertilizer dose and bio-fertilizer inoculation on growth and yield of pigeon pea. Indian journal of Agronomy 28:214217. 


\section{How to cite this article:}

Gouthu Naga Panchavathi, B. P. Dhyani and Shahi, U. P. 2020. Effect of Nitrogen Levels and Scheduling on Growth and Yield of Pigeon Pea in Integrated Approach. Int.J.Curr.Microbiol.App.Sci. 9(07): 1230-1238. doi: https://doi.org/10.20546/ijcmas.2020.907.142 